\title{
Social Media as a Factor for Promoting Entrepreneurship - the Middle East \& Oman Scenario
}

\author{
Baby Sam Samuel ${ }^{1, *}$, Joe Sarprasatha ${ }^{2}$ \\ ${ }^{1}$ Department of Management, SRM University, Tamilnadu, India \\ ${ }^{2}$ Department of Management, SRM School of Management, SRM University, Tamilnadu, India
}

Email address:

s.babysam@gmail.com (B. S. Samuel)

\section{To cite this article:}

Baby Sam Samuel, Joe Sarprasatha. Social Media as a Factor for Promoting Entrepreneurship - the Middle East \& Oman Scenario. International Journal of Economics, Finance and Management Sciences. Vol. 3, No. 5, 2015, pp. 483-493.

doi: $10.11648 /$ j.ijefm.20150305.20

\begin{abstract}
This study is focusing on to establish the Social Media as a factor for promoting entrepreneurship in Oman \& the Middle East region. This was done by social media in general public as well as by Businesses \& entrepreneurs. The results generated based on the social media usage in Oman and Middle East with respect to Facebook, Twitter, LinkedIn, Instagram. In terms of theoretical survey, this article clearly explains that all nations, aside from that these countries had more than $90 \%$ of their populace utilizing long range informal communication destinations.
\end{abstract}

Keywords: Social Media, Social Networking, Sultanate of Oman, Entrepreneurship, Online Entrepreneurship, Entrepreneurship Policies, Social Media Marketing

\section{Introduction}

Social media is a new phenomenon that has changed the face value of the business environment and the way it has been operating. In present scenario, every business needs to get hold of their resources in order to be sustained in the market and with the integration of the social media in the business line, the entrepreneurs are able to gain access to resources more than earlier times. The implementation of the social media in the business sector has also helped to improvise their worthiness, cultivate strategic partnerships and enhance their contact with suppliers and clients (Zahra, 2011). It has become more important and challenging for business owners and marketers to better understand the effectiveness of social media as a communicating and marketing tool and how they can significantly able to grow their market segment with the help of social media as well. Social media are playing a major role in promoting entrepreneurship because the more the product will be known to the audience the better it will generate the target audience for the entrepreneurship and ultimately gives rise to the business.

This study is focusing on establishing Social Media as a factor for promoting entrepreneurship in Oman \& the Middle East region. This was done by social media assessment of general public as well as of Businesses \& entrepreneurs; the study used descriptive research design. After researching several factors, it has come into sight that integration of social media in the businesses and entrepreneurs offers a greater market accessibility which in turn has a significant impact upon the growth of the business and entrepreneurs.

In addition to the fact that social media offers a platform where it allows business and entrepreneurs to communicate rapidly and economically with clients as well as it also allows them to build a database that can be used to generate business leads that may translate to enhanced the sales and results growth of the business. The study recommends that the policy maker viz. Government should be enthusiastic towards on-going trends of technological adaptation by businesses \& entrepreneurship and should come up with the policies that can promote entrepreneurship (Djeflat, 2013). The business and entrepreneurship world is not immune to any impact that may arise, but social media is one such phenomenon that has boomed in the business market in less time. The users of social media have the capability to share their views and encounters regarding the products and this assist in creativity, innovative ideas, open communication and sharing of knowledge among users as well. Twitter, Facebook, Skype, You Tube and discussion forums are some of the examples of social media tools through which entrepreneurship and business can achieve their successful growth and provides 
effective ways by means of which it can promote entrepreneurship (Alrawadieh \& Johnson, 2012).

\section{Social Media}

It is a computer mediated tool that permits people to openly share their views, create and exchange information, ideas, pictures or videos with the world in virtually and is defined as a group of internet based applications that is being created based upon the ideological and technological foundations of Web2.0. It also allows the creation and exchange of user-generated content and introduces itself as a substantial and omnipresent in order to bring changes into the world of communication in between business, communities, organizations and individuals (Goby \& Erogul, 2011).

These are the prime changes that focus of the emerging field of techno-self-studies. Social Media is far different from the traditional and industrial media in several ways, including usability, quality, frequency, reach, immediacy and permanence. It operates in a dialogic transmission system which has many sources to many receivers which is in contrast to traditional media that utilizes and operates through the mono-logic transmission model (one source and too many receiver transmission models).Social media has been broadly identified as relatively easy on the pocket and globally accessible digital tools that facilitate any person to publish and access information, build relationships with known and unknown people and collaborate on a common effort. With this handy platform's integration over Internet much helps the business also in order to stay connected with their target audience and it also provide effective help towards promoting entrepreneurship (Roomi, 2013). The prologue of the social media technology is accelerating these days and it can be expected that it has the similar impact on businesses and entrepreneurship now and into the future. Due to availability of the new technologies, businesses that learn to utilize the new technologies gain great advantages from which some of the best-known examples are Microsoft, Google, E-bay, and Amazon and so on. In fewer time frames, social media has become one of the loved mediums present in the globe for the youths as of now and with this social media marketing is the hottest new marketing concept that is presently in trend and almost every business owners as well as entrepreneurs wants to know how social media can able to generate value for their business and entrepreneurship (Karatzogianni, 2013). There is a thin and clear difference present between a social media and social media networking sites, which is being generally misinterpreted by users. Social media are the tools by means of which sharing and discussing of information is much easier and can be described professionally as a kind of online media that gives confidence to each and every member for effective feedback and contribution towards discussions (Sikdar \& Mitra, 2012).

\section{Oman \& Middle East}

Social entrepreneurship responds to Oman and Middle
East communities that have been marginalized or excluded by existing market performers and non-market institutions; however, it aims for a revolutionary transformation of the pattern of production that is often being associated with the entrepreneurship at large but in case of social entrepreneurship applies to social challenges (Salamey \& Pearson, 2012). This must include a strategy for achieving financial sustainability in the business. These countries are oppressed area in the growing literature on entrepreneurship. Social media has a significant impact in these regions because it is flourishing in the region. Approximately 3.7\% of the people from these areas uses internet from which some of the most popular sites include Twitter, Face book, Linked In, You Tube and so on. Particularly in Egypt, since 2012, more than 1.6million people have joined Face book; however Turkey and Djibouti have seen decreased numbers in the Face book members (Karatzogianni, 2013). The impact of social media in these countries is that, it has inspired the people to want change which has offer voice to them across the globe. Social media also have an affirmative impact on tolerance across these countries, since the Internet is connecting people from different folks around the world. At the time of Arab spring, social media was being utilized to help talk about the issues with politics and is also used to discuss over community and religion issues. Apart from that, social media holds the potential in order to play an important role in amplifying skill sets, supporting entrepreneurship and enhancing employment prospects more often across the region. In this manner, they get utilized to the Social Medias (Ghannam, 2011).

\subsection{Oman}

Social Media which is a vast set of online technologies, sites and practices that are being utilized to share opinions, perspectives and experiences and fundamentally it is about the conversation / communication that has brought revolutionary change for promoting entrepreneurship by bringing together populace from across the globe into one a single platform. In order to promote entrepreneurship, an entrepreneur must have to communicate with the folks, suppliers, customers and distributors. Starting up an entrepreneurship requires lots of researches and an entrepreneur can find information on almost each and every subject rapidly with the help of social media. In the present scenario, many government agencies, private organizations, business, universities are offering information on the social media, usually at no cost social media can share it to promote entrepreneurship. It is the safest, easiest and a user friendly way present to find information while promoting entrepreneurship via social media (Zerovec \& Bontenbal, 2011).

Websites, visual information and pages of print which are linked together electronically and provide a platform to the entrepreneurs for the inception of the new business and its services as well as products and promote it in the social media to reach huge market audience. Websites can be created and updated more frequently than that of printed promotional material in general. Entrepreneurship can also 
offers information about their products and services via social media websites and promote their business over there for free of cost (Zerovec \& Bontenbal, 2011). Most of the social media will promote an entrepreneurship websites whenever a selected set of search terms is being used. Online shoppers for example, often seek the help of Face book, Twitter and You Tube to find business that offers specific products and services as well as can promote their online shopping business by utilizing the concept of social media.

Social media marketing has taken the idea of price beyond fiscal to take in social, psychological, geographic and other rewards for monitoring the everyday behaviour of their clients towards their products. In these countries, Social Media as well as social media marketing are on the voyage towards gaining popularity in the entrepreneurship market. For example, customers are no longer visit items in the yellow pages of the postal directory, but instead they search for them on the internet or social media (Goodliffe, 2013). While promoting entrepreneurship via social media in the traditional sales cycle, customer relationship management or CRM forms a data driven under structure which gives power to an overall customer lifecycle. While promoting entrepreneurship in the social media where consumers are playing an essential role of the trade process, CRM is being adopted by the entrepreneurship to support their new role of the consumers. By doing so, this offers a highly valuable window of insight into what their consumers are really thinking about their products and services as well as to know more about what they are likely to do next.

In the adoption of social media tools like Face book, Twitter, Google, Instagram and You Tube and so on, all entrepreneurships need to capitalize on having talented yet dedicated employees who will give their best shot and helps the entrepreneurship for boosting up the productivity and efficiency of the business which is very important in any entrepreneurship (Jarvis et al., 2013). This has lead towards the rise of a new concept called Social CRM, which is just a significant approach to entrepreneurship that formally acquainted with the role of the consumers being as a key in recognizing and managing conversations around the entrepreneurship.

Recruiting workforces who better understand the social media is the key towards opening the success gate for the entrepreneurship. Promotion over social media for the entrepreneurship can amplify the entrepreneurs to promote their goods as well as services over social media and offers access to a large and growing market. From countless of earlier research it has been come into sight that, around 627 millions of people were shopping online worldwide and the source of the information is being received from the social media only. By promoting the entrepreneurship over social media, any individual or entrepreneur can gain a national or else international group of potential consumers for their business (Kapugama et al., 2013). There will be an international recognition for the products and services for the entrepreneurship as well. Some of the businesses like books, airline travels and so on can be granted as the most effective examples in which social media plays a pivotal role to promote their business online and gives them ample of loyalty as well as trusted consumers.

In Oman, it has been come into sight in these days that, they have been while adapting to the new day technologies and beginning to purchase merchandise from the locally based business completely on social media. In the present scenario, just throwing a Smart phone or a tablet will definitely boom an entrepreneurship in this region because, by doing so it will raise huge bonus for the entrepreneurship due to availability of the internet and social media all the time (Kapugama et al., 2013). Because of the social media tools like WhatsApp, Instagram, Google, You Tube, Facebook, Twitter and so on and due to the presence of high local demands, these two regions have created huge demands of the food industry those are making pretty good sales at the end of a week.

Many social media based entrepreneurship have permanent jobs and do trade on the platforms for which acquiring consumers mostly from these countries, but also sometimes they get their consumers from overseas. Some of the social media entrepreneurships are even catching the eyes of the traditional brick and mortar shops that are now being started to showcase their products on their racks (Malik \& Awadallah, 2013). As of now, just name the entrepreneurship that is not getting to use of social media for promoting entrepreneurship. The total number of the single social media tool that is Face book has around 548940 of users present in the Oman itself and it gradually increases to 93320 by the end of the last six months. This is the current Face book statistics of the Oman region only then how many people are staying connected with the social media just think it and if an entrepreneurship started to think about promoting its business over social media then how rapidly it'll go viral over social media networks, just imagine (Seto, 2011). Therefore, social media is best proven for starting up any promotion for the entrepreneurship.

\subsection{Middle East Regions}

On the counterpart, $88 \%$ of the Middle East social media users are getting online on a regular basis. The benefits that social media is offering to the entrepreneurships includes brand awareness, accountability, business transparency and strengthened relationships with the shareholders as well as with the consumers. Whether social media is being used for promoting any small entrepreneurship or for any giant entrepreneurship, it equally treats both the entities and provides the safest, easiest and most effective yet lucrative way of establishing communication between consumers and entrepreneurs (Ottaway, 2012). It is very much crucial to know how advertisement and discount is playing a significant role in order to promote entrepreneurship. Once a month or occasional special discounts could make wonders towards the overall sales of the products and services; however, even though there are countless of advantages of doing entrepreneurship over social media, but there are also numerous scams are attached with it. Let's take an example 
of one of the well-recognized freelance graphic designer and photographer popularly known as Md. Kindy. He is receiving countless of likes and comments on his Face book social media site where his photography was based in the fashion line. One of his friends Chndy guides him to better understand that which products are in current trend and demand. Likewise, there are countless of examples present as of now who got advantages by promoting entrepreneurship over social media (Ottaway, 2012).

Many social media based entrepreneurship have permanent jobs and do trade on the platforms for which acquiring consumers mostly from these countries, but also sometimes they get their consumers from overseas. Some of the social media entrepreneurships are even catching the eyes of the mortar shops and traditional brick that are now being started to showcase their products on their racks (Malik \& Awadallah, 2013). As of now, just name the entrepreneurship that is not getting to use of social media for promoting entrepreneurship.

Even leading banks are nowadays in the social media for the obvious reasons of promotion of their entrepreneurship and also it benefits them in order to generate and gain people's attention towards them. The very first thing that is being required to sustain the social media or any other online platform of an entrepreneurship is the appropriate promotion and maintain the communication channel working with their consumers without which the entrepreneurship will slowly start to face the down fall and gradually it will decrease the customer's trust over the entrepreneurship (Seto, 2011).

\section{Social Media Usage in Oman \& Middle East (Statistics) by General Public}

\subsection{Oman}

Being a third largest country of the AGCC countries boarding Yemen, Saudi Arabia and the UAE, Oman is lying on the southeast corner of the Arabian Peninsula. In Oman, the commercial journey of the oil export has been started in the year of 1967 and ever since then it has been playing the major contributor role towards the GDP of the region. The introduction of the sixth five-year plan in this region by their government encourages much entrepreneurship to set industrial development of SMEs (small and medium enterprises). The plan also gives importance towards generating anonymous employment opportunities for the populace via Economically Feasible Labor Intensive Production facilities (EFLIP facility), though there is no separate policies are presented for the Small and Medium Enterprises, the Oman government has taken on some definite steps towards the Oman's development bank loans, equity funding and incubator facilities via youth fund and micro-business facilities provided by SANAD program. The entrepreneurship development amenities provided by means of Intilaaqah represent contributions by the private sector
(Gelvanovska et al., 2014). These programs are aiming towards promoting the SMEs in Oman region; however according to Michel Porter if the country will focus more onto its certain priorities then Oman can become a role model for the vicinity of the region. These certain and significant priorities includes launching of a comprehensive program for the entrepreneurship, developing of a cluster strategy is very much crucial and development of the strategy to attract more and more investment for this region.

\subsection{A Popular Social Networks in Oman}

With the inception of Smart Phones, social media uses is boosting up rapidly due to which many countries enjoy high levels of social media penetration including In these countries region's populace. With around 74 millions of users, Face book remains the most popular social media network in the in these countries which is twice the users of Twitter and the number is still rising up. Besides that, Instagram is the leading social networking traffic generator present across various countries that are contributing more in helping entrepreneurship as well as populace to stay connected with the world. Around $69 \%$ of the teenage mobile internet users are using WhatsApp each month in the Oman; however this social media channel is the Qatar's leading social media service present across all the social media application groups (Metcalfe et al., 2011).

\subsection{Middle East}

On the contrary, the Middle East is a region that is producing great hope and offering great change to its vicinity. Besides that, many of this region's populace is facing inequity, poverty and other sorts of development issues. Additionally, unemployment is the most dangerous virtual insect that is present in these countries and is commonly infecting the youth; one emerging approach to tackle these issues effectively is entrepreneurship (Gelvanovska et al., 2014). Entrepreneurs are the saviour for these countries as they have the potential for identifying, test and develop innovative solutions towards difficult problems. Entrepreneurship combines business with innovation skills to create optimum solutions for processing effectively to the social, economic and environmental issues as well for enhancing the quality of life in these countries for their consumers and strengthening the broader civilization.

Entrepreneurship utilizes its skills to develop new corporations or bring innovation to the already established units. Some of them put into practice their new ideas and others just modify some of the proven approaches to better suit the circumstances of the Middle East regions and different sectors or geography. Though schemes on a range of problem including edification, employment and microenterprise, the environment and sustainable development, health, media, culture, peace and good governance and more, entrepreneurship as well as entrepreneurs are having an increasing impact on the people's live in the Middle East region (Jamali, 2014). But more can be done and 
entrepreneurship can open a success gate towards reaching more communities and people. According to Synergos, enhancing the lives of populace in poor and marginalized society necessitates a systematic transformation. Such transformation can only be obtained when folks work in partnership with other citizens, other sectors of the society and various institutions to deal with the root cause of the issues and inequity.

The expansion in the social media has translated these countries into greater efforts towards entrepreneurship and with implementation of the social media in these regions, people are starting to understand that they can get used to social media and entrepreneurship to develop social change and are contributing more towards enhancing entrepreneurship to set off their own business or generate awareness in their community (Jamali, 2014). According to Mourtada, there are hell lots of positive things that can get you to have a taste of success by simply using the social media. There are countless of efforts present in these countries, those are aimed towards the development of the entrepreneurship, but among them technology is one of the finest ways which can get the populace socially involved in the in these countries.

\subsection{A Popular Social Networks in Middle East Regions}

The top most social media used in Saudi Arabia is Twitter. The average, for roughly $47 \%$ of all Twitter traffic in the region affected by the fact that half of the Saudi population of Internet users prefers to use Arabic online, $74 \%$ of all Tweets by MENA users are in Arabic (as compared to only $18 \%$ in English).You Tube is one of the largest and mostly used sites on the Internet, and its content is easily and widely shared on social media.

Social media helped the folks to be in connection with their long-lost friends and it also offers necessary help to the entrepreneurship for getting their target audience for their products. According to research and researchers, around 58\% of the respondent to the survey using social media for staying connected with their friends and beloved ones while approximately $24 \%$ respondents have strong believe in exchanging their valuable views and information with the world and experiences various products or services and stay connected with the entrepreneurship as well as world for keeping them up-to-date. However, there are others (around $16 \%$ ) present those who are taking part in the social media to just play games and participating in the contests offered by many entrepreneurships (Dewey et al., 2012).

This concludes that through social media, entrepreneurship have ample opportunity to communicate with their target audience and offer them their kind of products or services to influence them to carry out and be the loyal customer for the entrepreneurship for long interval of time. Undoubtedly, social media is a fast growing platform present for the entrepreneurship in almost all the sectors and acts as an effective tool because it is the best proven way to reach out the market segment without including towering cost into their account.

The social exchange has been increased among the entrepreneurship in mid-80's and extended in to small and medium enterprises for which entrepreneurship have become a productive part for the application of the social media to achieve subsequent success. Most probably, each of the entrepreneurship has developed social media networks and organizations that smoothes the progress of gaining access to the information as well as products and services (Metcalfe et al., 2011). Entrepreneurial activities offer huge employment opportunities and enhance competitiveness as well. Nowadays, researchers and policy makers across the orb are on a voyage to learn how social media can encourage the entrepreneurial endeavors and understand more the benefits of it towards the entrepreneurship (Autio, E. (2013).

\section{Social Media Usage in Oman \& Middle East (Statistics) by Businesses \& Entrepreneurs}

Early days, internet includes messaging through e-mails or via message boards and chart rooms, but these days are taking as the modern era of internet where social media is the king present for the folks as well as for the business and entrepreneurs as well. According to business point of view, social media is paid, earned and owned service provider present for the businesses and entrepreneurs where paid service includes internet advertising, PPC- search marketing, and Mobile advertising, sponsorships, paid applications. Earned service includes social media pages and feeds, word of mouth, user forums, News, PR and announcements activities, blogger relationships. And lastly owned service includes to the brand and product of the websites, Mobile brand and product websites, proprietary mobile applications, customer care services, proprietary digital content, proprietary blogs. Social media is the ongoing conversation of the planet in terms of businesses and entrepreneurs (Celidoni, 2013). In the increasingly connected society, building up a social media presence is as commonplace. Whether it is a small scale industry or a giant business, social media can help the businesses as well as entrepreneurs to increase the visibility, profits and the number of consumers. It is the one and only key that is present for the businesses and entrepreneurs which are linking social media activity with the business strategy. For achieving success in the businesses and to be an effective entrepreneur in the business there are some certain things which have to be taken into consideration and those are:

- Choosing the appropriate platform and practices

Boosting the social media use for the business means choosing the best and one of the finest platforms as well as practices that will perfectly fits through the core business strategy. In most of the cases, the objectives of a social media strategy are to amplify the reach and visibility of the organization or business. Hence, it would make sense to consider the fostering of a social media presence on most of the businesses. For example, Face book offers the business countless of target audience for the business, but social media 
platforms like Pinterest, Instagram and Tumblr have the highest growth rate for the business.

- Setting up goals for the business where social media can be effectively used

No doubt, the location, size and purpose of the business will naturally affect the social media goals of the business, but still many entrepreneurs and businesses are using the social media platforms in order to increase referral traffic for the business website, boosting up the business credibility, drive lead generation or the e-commerce purchases, demonstrate a corporate identity and culture that makes folks more likely to want to work with as employees or customers. Apart from these, social media platforms also increase the quantity of feedback that business receives from the leads and consumers (Celidoni, 2013).

One of the biggest challenges present for an entrepreneur is getting the word out about a new business to potential suppliers, investors, consumers and the media for which entrepreneurs have been so fast to hold close social media as a communication tool to as many people as possible. If social media is being utilized skillfully, many believe that it can help to set competitiveness between the small business and their competitors.

\subsection{Oman}

Business and entrepreneurs from the Oman region is being widely used the Linked In social media network for strengthening the relationship between customer and business as Linked In is a reliable business oriented social media platform present in the online source. $79 \%$ of the Oman business and entrepreneur index are using at least one of the social media platforms like Twitter, Face book, You Tube or corporate blogs. However, Twitter is the most popular social media tool present among the businesses with having almost two-thirds presence on the social media which will be approximately $65 \%$. At least one-half are reaching towards the audiences via Face book and You Tube and another onethird maintain their business over corporate blogs. Oman has an online forums combined users around 230,000+ with having 156,200 active Face book users only (Donald Hawley, 2011). The region is also having $2000+$ twitter users and $86 \%$ new blogs as compared to the last year demographics. Business and entrepreneurs should implement social media in order to compete regionally, nationally and globally. It can also provide a space where business as well as entrepreneur can do own branding quite effectively at low-cost which is negligible generally.

It is well-known that how powerful the word of mouth is and in Oman, Social media can be even more powerful tool to be used at business to get advantage out of it. Nowadays, social media is a great teacher present in the digital world and with the implementation of social media in business; entrepreneurs can become a successful leadership quality holder as it teaches them to be the business leader always, not a follower. In the region like Oman, social media penetration offers the business and entrepreneurs to know what their potential prospective customers really want and can provide much help towards building up a trusted community where sharing of information, ideas etc. are being easily possible. Apart from all these social media also gives the business and entrepreneurs ample solutions towards reputation management (Achy, 2013).

\subsection{Middle East Regions}

On the contrary, it is very much true that for any new online business and entrepreneurs to sustain in the market of Middle East, a passionate team of web design experts is very much essential. Social media is generally ignored from planning to function of the business strategies that eventually results in unanticipated results. It cannot be possible to meet the cross expectations by simply ignoring the $88 \%$ of social media users from Middle East region. Without any doubt, having a strong corporate presence over social media channels is the integral part towards having the taste of the success. The benefits that business are gained from social media channels are

- Brand awareness

- Business transparency

- Accountability

- Strengthened the relationships with key stakeholders

But along with the social media channel's benefits, there are risks also present. A single wrong message or poor interaction with the consumers or any negative comments via social media will collapse the entire business (Alhabidi, 2013). Therefore, before adapting to any particular global trend of social media, it is better to tailor that for particular business needs and if possible considering the cultural and demographic factors of the Middle East region is vital. In the Middle East region, business here depends upon the relationship based culture, thus being as an entrepreneur on social media channels doesn't mean losing personal contacts, but actual entrepreneur should run all of the social media accounts in order to better adopt platforms supporting to the videos in which entrepreneurs could able to directly communicate with the target audiences (Weber, 2014).

Around $30 \%$ of the Middle East's inhabitant's fall under 15 to 29 years of age which is accumulated as 100 million of the total population of this region, any business here couldn't ignore such a vast audience if willing to achieve target audience. Linked In outflanks Twitter crosswise over numerous Middle Eastern nations from which most essentially originates from the UAE where the business and business visionaries centered system comes to more than $12 \%$ of the populace contrasted with around 3\% for Twitter. Centre East area generally known for its backward government strategies and shady human rights practices and use of social media in this region are actually gaining huge grounds.

In the year of 2013, there are more social media business and entrepreneur users present in the Oman and Middle East, but the counting doesn't stop there and over the course of the next four years of analysis, it has been anticipated as social media will give a massive growth in these developing economies of these two countries and throughout world as well. In the year of 2014, it has been seen that the consumer 
shopping behavior has evolved speedily and with integration of the social media in the business like online shopping through mobile devices is the new norm and the shopping experience has become an increasingly more social with the help of the social media platforms like Twitter and Face book (Weber, 2014).

\section{Cases of Social Media Helping Omani \& Middle East Entrepreneurs}

With the penetration of the social media in the regions like Oman and Middle East, long gone are the days when it was just taken as posting of snapshots with the friends and letting them to know what you have in your lunch. Present days, social media has become a crucial and significant business tool which entrepreneurs can no longer disregard. With the boom in the technological field, social media is present everywhere nowadays. People use it to stay in touch with their friends and family whereas business enterprise uses it for buying decisions and develop new relationships with their customers. Many entrepreneurs are unwilling to get in contact with the social media because of the lack of information. They are unaware of the benefits that social media can offer to them and their business as well. However, there are many entrepreneurs who use social media regularly for moving their business forward. When social media is harnessed properly, it can help the business in order to propel towards a new level of success.

\subsection{Oman}

With the penetration of social media in the regions like Oman, countless of cases has been come into view in which social media is helping the Oman entrepreneurs in various ways. Some of them are illustrated below (Weber, 2014).

Rumaitha al Busaidi which is a French pastry making enterprise established in the Oman region. Instagram which is one of the best suited social media tool present in the online server much helps them in order to achieve their marketing objectives. Whenever public demands came to the market, one can easily go to the business's Instagram page and can browse the entire gallery which makes them to have the complete array of products that the business offers to the folks. Not only have that, one can also place an order based on his /her choice of colour and flavour of the pastry. A phone conversation would settle the price and venue for picking up the order. After making purchase, some of the users have had complemented the business over the enterprise's Instagram page and add satisfactory comments into it. Soon, the word starts spreading around and gradually the list of the customers also increases along with it. Slowly, it goes viral over internet and folks from the Oman region are very much desperate as of now to have a taste of the delicious pastry and by the end of the day the number reaches towards sky-scraping (Weber, 2014). In this case, social media offers a platform to the pastry business where seller increases its marketing objectives and became one of the success businesses in the Oman region. This concludes that people from Oman are nowadays beginning to purchase merchandise from locally owned businesses based completely on social media.

\subsection{Middle East Regions}

Countless of artifacts shows that people in the Middle East region are well-known and well-connected with the internet especially via social media across all age groups. Without any doubt, younger generation is more connected with the social media than that of elders in this region. Local businesses are using social media site like Face book as a web portal for retail, with payment usually on delivery. For examples Foulard, Fanilla Couture, Anayah whereas the Van Damme Volvo ad was spoofed in order to generate a humorous commentary on financial hardships in Jordan and Gaze; cities of Middle East. Around 67\% say that Linked In helps the entrepreneurs in order to build new business leads and drives them towards having the taste of success. In Middle East, LinkedIn users use the platform to make more informed business decisions and $64 \%$ of the folks see LinkedIn as a credible source of information. Arab Vines has 11,004 likes on Facebook. Local vines includes Palestinian, Lebanese, Egyptian, Syrian, Sudanese Vines from which Arab Keek Facebook page has 441,342 likes and 58,282 populace talking about this. Use of Instagram is present as the growing trend of business present in this day. With the help of which local businesses like Gulf Center (a catering enterprise), 3abella (Abaya sale KSA), Foulard (Hijab sale KSA) and so on are setting the high standards of the respective enterprise by using social media.

$86 \%$ believe that around $90 \%$ social media empowers the entrepreneurs via branding and marketing, 86\% tapping into wider markets and $84 \%$ entrepreneurial spirit within the corporations. $81 \%$ agree that having national social media policies would facilitate better use of social media in the workplace. Around $70 \%$ of social media users especially youth can be introduced into the workforce through matching job and $84 \%$ towards up-skilling. Demographics shows that around $85 \%$ of the folks are being influenced by social media in the workplace by triggering more customer satisfaction and increasing trust between co-workers is present with $78 \%$ which is boosting intra-agency collaboration among them (Weber, 2014).

A social media strategy is very much essential if an entrepreneur is going to pay off his/her investment. Social Media is a decent approach to advance a business or brand. We can take an example of Facebook on the grounds that it is the most prominent social media medium for business/brand advancement. Any business person can straightforwardly convey and can share his perspectives in regards to his image He can spread mindfulness about his organization and brand/product. One can make a fan page including his image/item name or focused on watchword which needs to rank up. One can make gatherings furthermore join the pertinent and can share his surveys about his product. An business visionary can utilize diverse Apps to advance his business. Now, LinkedIn is additionally a Business to 
Business social systems administration site where one can advance his image a great deal means influence its components for brand promotion. And at twitter, one can mindful his business with in 140 characters. He can declare any new dispatch or any new item inside of 140 character limit. So, Social media is truly an extraordinary approach to get a great deal of activity for a business.

Business visionaries can utilize online networking for individual marking and building an impact inside of their field and industry. They can then utilize this impact towards naturally (and not into quite a bit of a limited time way) build mindfulness for their organization or item.

They could likewise utilize social networking to assemble mindfulness for their organization when it is in its initial stages. The old style promoting and advertising routines may even now be required yet social networking furnishes them with a less expensive choice to advancing their organization. Business visionaries have a tendency to discover themselves on restricted spending plans as they develop their business (Jarvis et al., 2013). Social networking gives a vehicle to limited or worldwide introduction, the chance to associate with potential or existing clients amongst numerous different advantages, however in particular, for nothing. The expense becomes an integral factor when you are prepared to delegate the creation and execution of a solid technique with the assistance of a committed outsider.

\section{Unexplored Potential for Businesses Across Oman \& Middle East}

The significance of social media tools can't be appreciated without being placed within the context of media culture in the Oman and Middle East. Over the last ten years, these two regions have experienced the highest rates of technology adaptation among all developing nations. According to Sir Bernard Lewis, Maybe the single most significant development is the adaptation of the modern communications. The newspaper, telegraph, radio, printing press and television have all change the face value of Oman and Middle East. Though internet and social media penetration has increased dramatically over the last several years, the technological capabilities of modern life have progressed in a relatively short span of time and have not been embraced by government that dominant the Oman and Middle East.

\subsection{Oman}

As internet and social media access has flourished across Oman, a highly complex and ambivalent relationship has been developed in between media and government in which Oman autocracies have encouraged internet and social media penetration in the name financial development while attempting to maintain control over the spread of media sources and information simultaneously (Jarvis et al., 2013). The utilization of social media as an effective means of transportation for organization and mobilization can be explained by several established theories of communication.
Each and every social media user is a potential rebroadcast to their own real world social networks and when internet use is awesomely concentrated among the youth, there is a minimal duplication present in the bush telegraph system as it is in most countries frequently found with low internet penetration. With its low entry barriers, social media tools offer an accessible platform for citizen journalism, defined as the use of digital media tools to report on dealings on the ground, uploading text and videos directly to the Internet or feeding the information and videos to media outlets. The dialogue taking place through Facebook, Twitter and other social media networks that was used by the mainstream media as a source during the height of the objections.

\subsection{Middle East Regions}

A survey by The Arab Social Media Report specified that in Egypt, the majority of Facebook users polled agreed that Facebook was being used most effectively to raise awareness of the causes of the movements within the country. The online forums or social media has enabled the general public to challenge the monopolies of power present in these two regions.

Whether intentionally or unintentionally, a final component to address is the ways in which social media can raise awareness of the ongoing revolution in these countries. The internet and social media can stimulate different users in different ways in the same manner that globalization affects to different users in different ways. The fundamental mistake that is made by these country people is the assumption that the social media is a deterministic one directional force present for either global liberation or oppression whereas in reality, it has allowed all these forces to flourish online (Zerovec \& Bontenbal, 2011). In these countries region it became evident that though Egyptian and Tunisian activists were seemingly capable to exploit the benefits of social media networking to achieve success, in other parts of the Arab states, protestors those are trying to replicate strategies are being utilized in Egypt were quickly crushed by the state led security forces by the end of the day.

The unexplored potential for business across these countries includes the areas to explore more to set business and those are:

- Who are the key audience for the business?

- Identifying the most appropriate platform for the business to engage with the business target audience

- Explore more and more towards how social media can increase the efficiency as well as effectiveness while without increasing the workload

- Agree to an overall approach to harness the excellent work that is being already undertaken by individuals around the facility

- Develop a social media strategy and set goals

Blog and Micro-blog creation and implementation of it in the social media network is the trinity of social media that is present in the online media these days. Apart from that, it is very much essential while listing up the potentials of the business that what audience will be the aim of the business to 
engage, what sorts of content is required, how often will the content posts and from where it will be coming from, who will be responsible for posting the content and engaging the community as well. It will be good if the audience will be students, alumni, partners and companies (Zerovec \& Bontenbal, 2011). While looking from the outside in what does business's audience look for and what the business's audience can sees should is the prime concern. To be efficient and effective use of social media to improve upon the existing communication but not replacing it, offer real-time information, promote events to the new audiences, the ripple effect is encouraging the sharing process, advocate transparency and openness. Message frequency should be based on daily and weekly basis where sharing of information, responding to the blog comments, tweets and Facebook posts should be on daily basis whereas posting of new blogs, including short videos that will describe more about the business, adding up an instructional article and participate in related forums should be done on weekly basis (Metcalfe et al., 2011).

Social media empowers individuals to become digital curators, creators, communicators, collaborators, critics and conversationalists to continue the discussion face to face. From wide spread social media networks, LinkedIn are an information goldmine present from which 5.7billion professionally oriented searches were being carried out in the year of 2012 .

It helps the business to build trusted and valued relationships. Sharing of news, assessments, surveys, industry articles authority pieces or request that devotees associate on hot and current points. Posts will show up on your Company Page and in the news feast upon the landing page of each of your supporters (Metcalfe et al., 2011). At the point when devotees like remark and share your message spreads to their systems and constructs viral appropriation.

Request that adherents like, offer, and remark on your overhauls. This helps spread your message to their whole system. Developing the follower community is playing a significant role while discussing about the unexplored potentials for business in Oman and Middle East. Keeping an eye on updated metrics can fine tune the messages and enhance the engagement. User follower analytics to gain a deeper understanding of the follower base, community growth and engagement levels. Leverage page analytics to learn more about the page traffic and activity and lastly knowing to compare between competitors' pages is a great way to identify whether business should explored or change the strategy or not. The major unexplored potential of business present in these countries is that these are not digitally distinct, dabbling, disused, and disastrous and disguised (Dewey et al., 2012). These are the things that people are actually seeing about the business when they make their search for the business online in this region.

\section{Conclusion}

The study established that social media being as a factor helps the entrepreneurship in these countries for promoting entrepreneurship. Many entrepreneurs have not fully understood and internalized the potential of social media for their businesses. Those who use social media do not optimally use tools because they use only selected tools due to some certain limitations present from infrastructure and technical capabilities. This means that businesses in these countries have not benefited adequately from technology and specifically social media despite of its wide usage by potential customers. This is a golden opportunity that could enhance entrepreneurship growth and gain a competitive edge against large business that traditionally have resources and have been in business for a long time. It is revealed that social media has broken down geographical barriers and foreshadowed new ways of doing business to those who are flexible and keen to adapt to changes in technology and business environment. This transformation into new methods of reaching customers and opening frontiers where small, medium and large entrepreneurship compete equally without traditional advantage that was previously enjoyed by large businesses. This presents an opportunity for entrepreneurship to target customers and create their niche in the new frontiers to build their market share and consequently increase their sales. This can only be done by flexibility and a positive attitude towards learning how best social media tools can be used to facilitate market access. This study also sought to find out if social media had affected how innovative entrepreneurship was and it found out that entrepreneurs in these countries had not been able to use social media to be innovative in their product offerings or operations, but social media networks can enable generation and sharing of insights as well as ideas on new innovative ways of doing business in an effort to better serve the customers.

Entrepreneurs have an opportunity to develop new products and services that suit customers' needs based on their feedback in social media and also communicate these developments to customers through the same media. This interprets into cost saving and financial growth for entrepreneurs which they desperately need as they are characterized by lack of adequate resources. Determining the effect of social media on the pricing of products availed by entrepreneurship and the way it can promote entrepreneurship, were two objectives of this study. The study revealed that pricing as one of the most flexible elements of marketing mix could be affected by social media but in a small meaning. This is through gathering of information on the appropriate details that could be added to products and services to enhance their value for money. The study also established that pricing does not necessarily interpret into cheap products and services but it is guarantee that it will offer profits to the businesses. The aspect of incentives and behaviours that resonate with people in pricing is also important when it comes to promotion of new products and services. Businesses in these countries must be aware that social media networks provide information to customers as well as increased choices. Entrepreneurs therefore, needs to be price sensitive the same way their 
customers are. The effect of social media on the customer relationship management of entrepreneurship was looked into Traditionally, customer relationship was largely based on transactional data and context. With the help of social media, the situation has changed in these two regions where social CRM has assumed as the significant importance. Entrepreneurship in these countries may have tapped into this element but there is still much room to further utilize Customer Relationship Management for their growth. CRM brings a magnitude of opportunities for businesses to communicate with consumers effectively and effortlessly as well as build databases that are necessary for future growth in terms of accessing new markets that will translate to increase.

Entrepreneurship today is being transformed from a transactional relationship to a social relationship, which is now more critical than ever that successful entrepreneurship use the effective engagement of the marketing principles to plan for successfully engaging their prospects and consumers before, during and after their purchase cycle of products and services which is the foundation base for this engagement is relevant information and high quality.

Successful utilization of the social media takes time and lot of patience and success over social media should not be expected overnight. Constantly listening to the artifacts and by proper measuring and learning entrepreneurship should prepare or bring adjustment into their strategy on the basis of what will be working as the best for them. Being as an entrepreneur, no doubt you have reached to your potential consumers and business stakeholders and build a trusted relationship with them. Social media is about making those existing trusted relationships deeper and it also helps to build new ones. With the penetration of the social media in Oman and Middle East, the entrepreneurship can reach like never before where businesses can embrace their consumers. With emergence of the social media, many businesses and communication has achieved success. Facebook alone have $500,000,000+$ active worldwide users where around 4500 corers pieces of content shared per month and is having 1,500,000 local businesses with active Facebook pages.

Entrepreneurship will succeed if:

- Objectives, goals and targets are crystal clear

- Social media profiles are focusing more on to users, updating frequently and content that is relevant, current as well as of interest

- Linked with other relevant famous social media networks for promoting entrepreneurship as well as encourage input and provide feedback

- Unused social media applications has to be removed

When not upsetting an administrational change, social networking discovers itself being utilized as a part of all the more humanly fashion in these countries locales. On the setting of the information gave by $5^{\text {th }}$ annual Arab Social Media report, Facebook has enrolled more than 55 million Arabs while Twitter came to 3.7 million clients. UAE is the nation with greatest Facebook usage at $41 \%$ while Saudi Arabia has more than half of the Arab active Twitter users. This tremendous increment is being possible due to the business environment present in these areas and of course the credit goes to social media users for making the entrepreneurship a living legend in these countries region and other parts of it.

The findings of this survey show that social media's growth gives a support to advancement and effects instruction in a positive way in the Middle East and Oman. Therefore, in this survey social media is not only helping the entrepreneurship to promote itself but also it provides ample solutions towards educating people especially the students.

This study clearly explains that all nations, aside from that these countries had more than $90 \%$ of their populace utilizing long range informal communication destinations. Also, here it has been noted that, Facebook is the mother of every single informal organization, with an incredible $94 \%$ of the reviewed individuals reacting absolutely to being active on it. Twitter was placed in second position with $52 \%$ client base and Google+ accomplished third rank with having $46 \%$ of respondents those are having activity on it. In any case, a ton of social networking worth of this area still lays undiscovered as seen here. The Middle East alone has a capability of 209 million new clients who could be conceivably utilizing one of the online networking stages for diverse purposes.

\section{References}

[1] Zahra, S. A. (2011). Doing research in the (new) Middle East: Sailing with the wind. The Academy of Management Perspectives, 25(4), 6-21.

[2] Djeflat, A. (2013). The Relevance of Science and Technology for the Arab Spring and the Key Role of the Knowledge Economy. In The Real Issues of the Middle East and the Arab Spring (pp. 169-193). Springer New York.

[3] Alrawadieh, Z., \& Johnson, D. (2012). Building Sports Tourism and Event Portfolios-Key Success Factors in Middle East Sports Tourism: A Case Study. London Journal of Tourism, Sport and Creative Industries, 6(7), 30-41.

[4] Goby, V. P., \& Erogul, M. S. (2011, August). Female entrepreneurship in the United Arab Emirates: Legislative encouragements and cultural constraints. In Women's Studies International Forum (Vol. 34, No. 4, pp. 329-334). Pergamon.

[5] Kabir, M., \& Rahman, M. S. (2012). Population projection of Oman: implications for future development. Education, Business and Society: Contemporary Middle Eastern Issues, 5(3), 163-170.

[6] Roomi, M. A. (2013). Entrepreneurial capital, social values and Islamic traditions: Exploring the growth of women-owned enterprises in Pakistan. International Small Business Journal, 31(2), 175-191.

[7] Karatzogianni, A. (2013). 11 A cyberconflict analysis of the 2011 Arab Spring. The Digital World: Connectivity, Creativity and Rights, 159.

[8] Sikdar, A., \& Mitra, S. (2012). Gender-role stereotypes: perception and practice of leadership in the Middle East. Education, Business and Society: Contemporary Middle Eastern Issues, 5(3), 146-162. 
[9] Salamey, I., \& Pearson, F. S. (2012). The Collapse of Middle Eastern Authoritarianism: breaking the barriers of fear and power. Third World Quarterly, 33(5), 931-948.

[10] Karatzogianni, A. (2013). A Cyberconflict Analysis of the Arab Spring Uprisings.

[11] Ghannam, J. (2011). Social Media in the Arab World: Leading up to the Uprisings of 2011. Center for International Media Assistance, 3.

[12] Gelvanovska, N., Rogy, M., \& Rossotto, C. M. (2014). Broadband Networks in the Middle East and North Africa: Accelerating High-Speed Internet Access. World Bank Publications.

[13] Jamali, R. (2014). Online Arab Spring: Social media and fundamental change. Chandos Publishing.

[14] Dewey, T., Kaden, J., Marks, M., Matsushima, S., \& Zhu, B. (2012). The impact of social media on social unrest in the Arab Spring. International Policy Program.

[15] Metcalfe, B. D., Mimouni, F., \& Murfin, T. (2011). 14 Turning neither to East nor West: social reform and a liberating ethics for leadership development. Leadership Development in the Middle East, 371.

[16] Autio, E. (2013). Global Entrepreneurship and Development Index 2013. Edward Elgar Publishing.

[17] Zerovec, M., \& Bontenbal, M. (2011). Labor Nationalization Policies in Oman: Implications for Omand Migrant Women Workers. Asian and Pacific Migration Journal, 20(3-4), 365387.

[18] Goodliffe, T. (2013). An exploration of structural factors and personal agency in the education to work transition context in Oman (Doctoral dissertation, University of Leicester).

[19] Jarvis, L. S., Petraud, J. P., \& Aqaba, J. (2013). Climate Change and Increasing Aridity: The Fate of Agriculture and Rural Communities in the Middle East and North Africa.

[20] Kapugama, N., Zuhyle, S., \& Perera, R. S. (2013). Mobile phone interventions for improving economic and productive outcomes for farm and non-farm rural enterprises and households in low and middle-income countries.
[21] Malik, A., \& Awadallah, B. (2013). The economics of the Arab Spring. World Development, 45, 296-313.

[22] Seto, K. C. (2011). Exploring the dynamics of migration to mega-delta cities in Asia and Africa: Contemporary drivers and future scenarios. Global Environmental Change, 21, S94S107.

[23] Information Resources Management Association (Ed.). (2013) Small and Medium Enterprises: Concepts, Methodologies, Tools, and Applications. IGI Global.

[24] Ottaway, D. (2012). Saudi Arabia's Race against Time. Woodrow Wilson International Center for Scholars, Middle East Program.

[25] Devarajan, S., \& Mottaghi, L. (2015). Middle East and North Africa Economic Monitor, April 2015: Towards a New Social Contract. World Bank Publications.

[26] Baporikar, N. (2012). Critical Review of Academic Entrepreneurship in India. Academic Entrepreneurship and Technological Innovation: A Business Management Perspective: A Business Management Perspective, 29.

[27] Farah, A. I. (2014). Factors influencing women participation in entrepreneurial activities in Mandera township, Mandera central division, Kenya (Doctoral dissertation, University of Nairobi).

[28] Celidoni, C. (2013). Made in MENA: Internationalization of Southern-European Enterprises in the Middle East and North Africa Region. The Zara case study.

[29] Donald Hawley, S. (2011). Reform in the Middle East Oil Monarchies. A. Ehteshami, \& S. Wright (Eds.). Sussex Academic Press.

[30] Achy, L. (2013). The price of stability in Algeria (Vol. 25). Carnegie Endowment for International Peace.

[31] Alhabidi, M. (2013). Saudi Women Entrepreneur Over Coming Barriers In ALKhober (Doctoral dissertation, Arizona State University).

[32] Weber, A. S. (2014). Linking Education to Creating a Knowledge Society: Qatar's Investment in the Education Sector. Handbook of Research on Higher Education in the MENA Region: Policy and Practice: Policy and Practice, 52. 